\title{
Occurrence of Plant-Parasitic Nematodes of Turfgrass in Korea
}

\author{
Abraham Okki Mwamula ${ }^{1,2}$ and Dong Woon Lee (D) ${ }^{1 *}$ \\ ${ }^{1}$ School of Ecological Environment and Tourism, Kyungpook National University, Sangju 37224, Korea \\ ${ }^{2}$ Department of Zoology, Entomology and Fisheries Sciences, College of Natural Sciences, Makerere University, \\ Kampala 7062, Uganda
}

(Received on April 13, 2021; Revised on July 8, 2021; Accepted on July 28, 2021)

Plant-parasitic nematodes are not only an important constraint on agricultural crop production, but also cause both direct and indirect damage to turfgrass, which is a ground cover plant. However, studies on plant-parasitic nematodes of turfgrass in Korea are scarce. A survey for plant-parasitic nematodes was carried out on 13 golf courses in Korea. The results yielded 28 species/taxa belonging to 16 genera and 12 families of plant-parasitic nematodes. Among the isolated species, Helicotylenchus microlobus, Mesocriconema nebraskense, Tylenchorhynchus claytoni, Mesocriconema sp., and Meloidogyne graminicola were the most prevalent species in all management zones. Twelve species were new records of plant-parasitic nematodes in Korea. Highest maximum densities were showed by T. claytoni, Paratylenchus nanus, M. nebraskense, $M$. graminicola, and $\boldsymbol{H}$. microlobus. Diversity $\left(H^{\prime}\right)$, was significantly higher in fairways compared to tees and greens, though species evenness $\left(J^{\prime}\right)$ and dominance (D) showed no statistically significant differences. This information is crucial in nematode problem diagnosis, and the subsequent formulation of management strategies.

\footnotetext{
*Corresponding author.

Phone) +82-54-530-1212, FAX) +82-54-530-1218

E-mail)whitegrub@knu.ac.kr

ORCID

Dong Woon Lee

https://orcid.org/0000-0001-9751-5390
}

Handling Editor : Sook-Young Park

(c) This is an Open Access article distributed under the terms of the Creative Commons Attribution Non-Commercial License (http:// creativecommons.org/licenses/by-nc/4.0) which permits unrestricted noncommercial use, distribution, and reproduction in any medium, provided the original work is properly cited.

Articles can be freely viewed online at www.ppjonline.org.
Keywords : diagnosis, diversity, golf course, incidence, taxonomy

Turfgrasses are some of the most widely planted ornamental grasses, and the turfgrass industry is among the most promising economic industries worldwide. Turfgrass is an essential resilient raw material used in the establishment of outdoor surfaces for sporting activities and other recreational operations, in addition to its natural role in soil stabilization (Vandenbossche et al., 2011; Zeng et al., 2012). Turf is not only used in commercial settings but also is a desired component in establishment of home compound and cemetery lawns (Kang et al., 2016). In Korea for example, turfgrass is utilized as home, school and cemetery lawn covers; in addition to the more crucial role in improvement of outdoor sports and recreational surfaces (Kang et al., 2016; Kim, 1991). The unique cushioning effect reduces injuries compared to poorly or non-turfed surfaces, especially in active contact sports activities like rugby and football (Gramckow, 1968). The turf industry is currently on the increase in Korea, with over 3,056 ha reported to be under sod production in 2011. Golf courses provide the biggest market (Lee et al., 2014). However, research on effective sod production is still in insufficient level; especially with regard to the prevailing turfgrass pests and diseases in Korea. A vast array of pests and diseases; primarily the fungal, bacterial and algal infections, plus coleopteran and lepidopteran insect pests are a threat on turf fields (Lee et al., 2014). More importantly, plant-parasitic nematodes (PPNs) stand out as unacknowledged or neglected turfgrass pests. This is normally due to the incapacity to identify nematode damage symptoms, and the most damaging species of economic importance.

Nematodes cause both direct and indirect damage on turfgrass (Vandenbossche et al., 2011). Their feeding ac- 
tivity rarely causes total turf death; however, nematodes impair the normal root growth and cause symptoms like root lesions, necrosis and galling, thus resulting into root malfunction for normal water and nutrient uptake (Walker et al., 2002). Additionally, root damage induced by nematodes provide pathways for entry of fungal and bacterial pathogens thus acting in a synergistic way towards reducing turf root quality, quantity and eventual turfgrass death (Vandenbossche et al., 2011). At high population infestations involving specific nematode-turfgrass combinations, total turfgrass death may occur (Hunt and Handoo, 2009; McClure et al., 2012; Vandenbossche et al., 2011). A number of PPNs have been implicated in damage of turf worldwide (Vandenbossche et al., 2011; Zeng et al., 2012). Root-knot nematodes (Meloidogyne minor) have been associated with yellow patch disease on turf in some European countries (Karssen et al., 2004). Over 50 species/taxa of PPNs have been recorded on turfgrass in Europe (Vandenbossche et al., 2011), while 24 species belonging to 19 genera have been so far recorded on various golf courses in USA (Zeng et al., 2012). Mesocriconema spp. (ring nematode), Helicotylenchus spp. (spiral nematode), Trichodorus spp. (stubby root nematode), Meloidogyne spp. (root-knot nematode), Hoplolaimus spp. (lance nematode), Hemicycliophora spp. (sheath nematode), Xiphinema spp. (dagger nematode), and Belonolaimus spp. (sting nematode) are considered to be more problematic in both warm and cool season turf (Zeng et al., 2012).

Control and management of PPNs in turfgrass systems involve mainly the use of nematicides in addition to proper cultural and phytosanitary routines (Crow, 2005; Fleming et al., 2008). The soil fumigant 1,3-dichloropropene (1, $3-D)$ has been the most widely used nematicide on golf courses (Crow et al., 2003; Crow, 2005). However, it's under restricted use in some parts of the world like Europe due to the side effects the nematicide causes on nontarget organisms and ground-water contamination. Nonfumigants like imicyafos and fosthiazate are recognized as better alternatives against PPNs (Kim et al., 2016; Wada and Toyota, 2008; Wada et al., 2011). However, these compounds are yet to be tested in turfgrass systems. As noted by Crow (2005), it is always desirable to avert nematode problems than dealing with established populations of a damaging species. Therefore, phytosanitary measures like using nematode free planting materials (turf mats) are important steps in establishing a sustainable turfgrass system. This can be promoted by conducting routine nematode assays on commercial sod farms before distribution is done to various golf courses.

Not until recently, information on the occurrence, tax- onomy, diversity and management of PPNs associated with turfgrass in Korea has been limited; with only two definitive species (Meloidogyne incognita and Tylenchorhynchus claytoni), presumed to be associated with turf damage on Korean golf courses (Choo et al., 1998, 2000; Khan et al., 2008). Meloidogyne marylandi and Tylenchorhynchus dubius have also been reported on zoysiagrass and Agrostis palustris (Kang et al., 2002, 2003). Other records have been limited to genus level (Helicotylenchus, Criconema, Pratylenchus, Tylenchorhynchus, Ditylenchus, and Tylenchus) (Kang et al., 2002). It is difficult to accurately diagnose nematode problems, as damage essentially depends on nematode species, initial population density, turfgrass species and soil properties (Perry and Smart, 1970; Vandenbossche et al., 2011). Thus, correct species identification plus an understanding of their diversity on turfgrass is a prerequisite for a successful nematode control and management strategy. A survey of Korean golf courses in April 2017 to 2019 uncovered several species of various suborders of PPNs; as detailed by Mwamula et al. (2020a, 2020b, 2020c, 2020d, 2020e, 2020f). However, it is evident that little is known about their diversity on turfgrass in Korea. This study therefore, was generally designed to provide the additional comprehensive overview regarding the occurrence and diversity of the main PPNs of economic importance on turfgrass in Korea; information that is crucial in the management of PPNs on turfgrass.

\section{Materials and Methods}

Soil sampling. Sod samples were taken from 13 golf courses in Korea in the summer of 2018 (Fig. 1). Areas with symptoms of nematode damage (stunted growth, less dense turf stands, shoot chlorosis, and root galling) were preferred during sampling. However, additional exploratory sampling was also done in areas with no reported nematode symptoms. In addition, sites were selected taking into consideration the different common grass species largely preferred on Korean golf courses (creeping bentgrass [A. palustris]; zoysiagrass [Zoysia japonica] and Kentucky bluegrass [Poa pratensis]); and (or) management zones (fairways, putting greens and tees). The information regarding the locality of samples, host grass species and soil properties is summarized in Table 1. Each sample consisted of 8-12 sod cores $(11 \mathrm{~cm}$ in diameter and $20 \mathrm{~cm}$ deep), taken using a standard hole cutter. Soil samples were placed in plastic bags and stored at $4^{\circ} \mathrm{C}$ before analysis to prevent nematode population changes (Barker et al., 1969). Seventy-one samples (781 sod cores) were processed in total. 


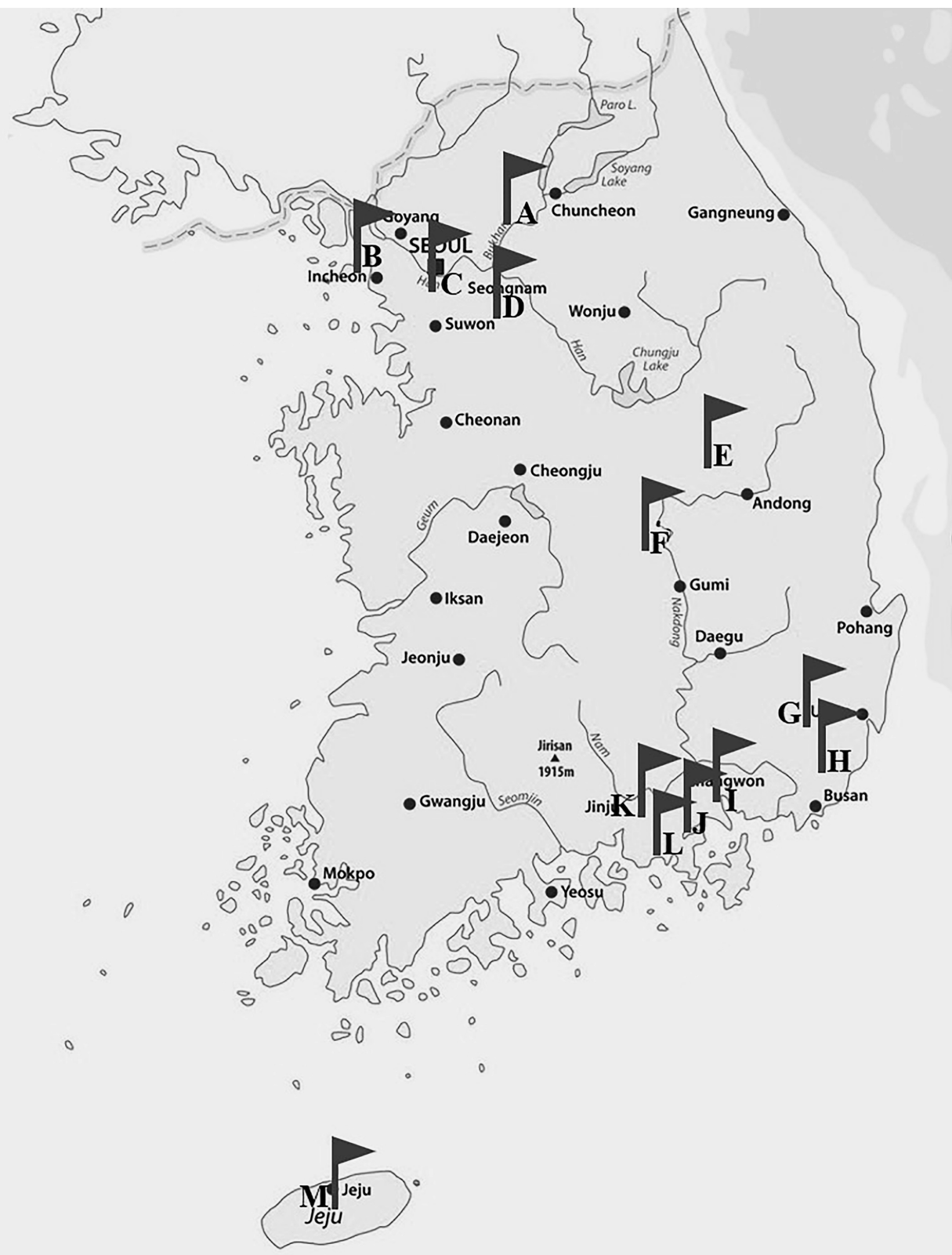

Fig. 1. Map of Korea showing the localities of golf courses sampled. (A) Gapyeong Benest golf club. (B) Sky 72 country club. (C) Anyang Benest golf club. (D) Glenrose golf club. (E) Hanmaek country club. (F) Apple Valley golf club. (G) Yangsan country club. (H) Dongrae Benest golf club. (I) Gaya country club. (J) Nobel country club. (K) Seokyung Tani country club. (L) South cape owners club. (M) Hallasan country club.

Nematode extraction. A $300 \mathrm{~g}$ subsample was taken from thoroughly mixed individual sod cores. Roots were separated from the mineral fraction by washing the $300 \mathrm{~g}$ subsample through $850 \mu \mathrm{m}$ nominal aperture sized sieve. The collected roots were subsequently macerated in a blender and added to the mineral fraction. Nematodes were extracted from the soil and the macerated roots by combination of various extraction techniques (modified Cobb's sieving; Baermann funnel; and centrifugation) (Jenkins, 1964), depending on target nematode species/form. Cysts (when present) were collected from $250 \mu \mathrm{m}$ aperture sieve and filtered with Whatman no. 100 filter paper to drain excess water. The contents on the filter paper were then directly observed under Nikon SM2 1000 stereo microscope to isolate cysts. The collected nematode suspension was examined under a stereo microscope, Nikon SMZ 1000 (Nikon, Tokyo, Japan), and PPNs were assayed (identified to genus level and enumerated). 
Table 1. Plant-parasitic nematode species studied; and details on the locality of samples, host plant, and soil properties

\begin{tabular}{|c|c|c|c|}
\hline Species & Locality of sample & Host plant & Soil type \\
\hline Hemicycliophora labiata & Gapyeong Benest golf club, Gyeonggi-do & $\begin{array}{l}\text { Poa pratensis } \\
\text { Agrostis palustris }\end{array}$ & $\begin{array}{l}\text { Loamy sand } \\
\text { Sandy loam }\end{array}$ \\
\hline Hemicriconemoides & Gapyeong Benest golf club, Gyeonggi-do & Poa pratensis & Loamy sand \\
\hline \multirow[t]{2}{*}{ brachyurus } & Gaya country club, Gyeongsangnam-do & Zoysia japonica & Loamy soils \\
\hline & Dongrae Benest country club, Busan & Zoysia japonica & Loamy soils \\
\hline Mesocriconema curvatum & Seokyung Tani country club, Gyeongsangnam-do & Poa pratensis & Sandy loam \\
\hline \multirow[t]{2}{*}{ Mesocriconema sp. } & Seokyung Tani country club, Gyeongsangnam-do & Poa pratensis & Sandy loam \\
\hline & Yangsan country club, Gyeongsangnam-do & Poa pratensis & Loamy sand \\
\hline \multirow[t]{6}{*}{ Mesocriconema nebraskense } & Seokyung Tani country club, Gyeongsangnam-do & Poa pratensis & Sandy loam \\
\hline & Dongrae Benest golf club, Busan & Zoysia japonica & Loamy sand \\
\hline & Apple valley country club, Gyeongsangbuk-do & Agrostis palustris & Loamy sand \\
\hline & Gapyeong Benest golf club, Gyeonggi-do & Poa pratensis & Sandy loam \\
\hline & Sky 72 golf club, Incheon & Poa pratensis & Sandy loam \\
\hline & Yangsan country club, Gyeongsangnam-do & Zoysia japonica & Loamy sand \\
\hline \multirow[t]{2}{*}{ Paratylenchus nanus } & Sky 72 golf club, Incheon & Poa pratensis & Sandy loam \\
\hline & & Agrostis palustris & Sandy loam \\
\hline Helicotylenchus asiaticus & Gapyeong Benest golf club, Gyeonggi-do & Poa pratensis & Sandy loam \\
\hline \multirow[t]{2}{*}{ Helicotylenchus caudatus } & Gapyeong Benest golf club, Gyeonggi-do & Poa pratensis & loam \\
\hline & Yangsan country club, Gyeongsangnam-do & Poa pratensis & Loamy sand \\
\hline \multirow{2}{*}{ Helicotylenchus dihystera } & Yangsan country club, Gyeongsangnam-do & Zoysia japonica & Sandy loam \\
\hline & Dongrae Benest golf club, Busan & Agrostis palustris & Sandy loam \\
\hline \multirow[t]{4}{*}{ Helicotylenchus microlobus } & Gapyeong Benest golf club, Gyeonggi-do & Poa pratensis & Sandy loam \\
\hline & Seokyung Tani country club, Gyeongsangnam-do & Poa pratensis & Sandy \\
\hline & South cape owners club, Gyeongsangnam-do & Zoysia japonica & Sandy loam \\
\hline & Sky 72 golf club, Incheon & Poa pratensis & Sandy \\
\hline \multirow[t]{2}{*}{ Pratylenchus penetrans } & Anyang Benest golf course, Gyeonggi-do & Zoysia japonica & Sandy loam \\
\hline & Sky 72 golf club, Incheon & Poa pratensis & Sandy loam \\
\hline \multirow[t]{3}{*}{ Pratylenchus zeae } & Dongrae Benest golf club, Busan & Zoysia japonica & Sandy loam \\
\hline & & Agrostis palustris & Sandy loam \\
\hline & Yangsan country club, Gyeongsangnam-do & Zoysia japonica & Sandy loam \\
\hline Pratylenchus scribneri & Gapyeong Benest golf club, Gyeonggi-do & Agrostis palustris & Sandy loam \\
\hline \multirow[t]{2}{*}{ Meloidogyne graminicola } & South cape owners club, Gyeongsangnam-do & Poa pratensis & Loamy sand \\
\hline & Hanmaek country club, Gyeongsangbuk-do & Zoysia japonica & Sandy loam \\
\hline \multirow[t]{2}{*}{ Meloidogyne marylandi } & Gapyeong Benest golf club, Gyeonggi-do & Zoysia japonica & Sandy loam \\
\hline & Seokyung Tani country club, Gyeongsangnam-do & Poa pratensis & Sandy \\
\hline \multirow[t]{2}{*}{ Heterodera pratensis } & Seokyung Tani country club, Gyeongsangnam-do & Poa pratensis & Sandy \\
\hline & Gapyeong Benest golf club, Gyeonggi-do & Poa pratensis & Sandy \\
\hline Heterodera avenae & Gapyeong Benest golf club, Gyeonggi-do & Poa pratensis & Loamy sand \\
\hline \multirow[t]{3}{*}{ Tylenchorhynchus claytoni } & Gapyeong Benest golf club, Gyeonggi-do & Poa pratensis & Sandy loam \\
\hline & Glenrose golf club, Gyeonggi-do & Zoysia japonica & Sandy loam \\
\hline & Nobel country club, Gyeongsangnam-do & Zoysia japonica & loam \\
\hline \multirow{2}{*}{$\begin{array}{l}\text { Tylenchorhynchus } \\
\text { thermophilus }\end{array}$} & Seokyung Tani country club, Gyeongsangnam-do & Poa pratensis & Sandy soils \\
\hline & Sky 72 country club, Incheon & Zoysia japonica & Sandy loam \\
\hline \multirow[t]{2}{*}{ Tylenchorhynchus annulatus } & Yangsan country club, Gyeongsangnam-do & Zoysia japonica & Loamy sand \\
\hline & Nobel country club, Gyeongsangnam-do & Zoysia japonica & Loam \\
\hline Psilenchus hilarulus & Gapyeong Benest golf club, Gyeonggi-do & Poa pratensis & Loamy sand \\
\hline Filenchus sp. & Gapyeong Benest golf club, Gyeonggi-do & Poa pratensis & Loamy sand \\
\hline Ditylenchus sp. & Gaya country club, Gyeongsangnam-do & Zoysia japonica & Loamy sand \\
\hline
\end{tabular}


Table 1. Continued

\begin{tabular}{llll}
\hline Species & \multicolumn{1}{c}{ Locality of sample } & \multicolumn{1}{c}{ Host plant } & Soil type \\
\hline Neopsilenchus sp. & Gapyeong Benest golf club, Gyeonggi-do & Poa pratensis & Loamy sand \\
& Yangsan country club, Gyeongsangnam-do & Poa pratensis & Loamy sand \\
Paratrichodorus minor & Seokyung Tani country club, Gyeongsangnam-do & Poa pratensis & Sandy \\
& Hallasan country club, Jeju-do & Zoysia japonica & Loamy sand \\
Paralongidorus koreanensis & Seokyung Tani country club, Gyeongsangnam-do & Poa pratensis & Sandy \\
& Yangsan country club, Gyeongsangnam-do & Poa pratensis & Sandy loam \\
& Dongrae Benest golf club, Busan & Zoysia japonica & Sandy loam \\
& Sky 72 country club, Incheon & Poa pratensis & Sandy \\
Xiphinema diffusum & Yangsan country club, Gyeongsangnam-do & Poa pratensis, Zoysia japonica & Loamy sand \\
& Sky 72 country club, Incheon & Agrostis palustris & Sandy \\
Xiphinema insigne & Yangsan country club, Gyeongsangnam-do & Zoysia japonica & Sandy loam \\
\hline
\end{tabular}

Nematode identification and enumeration. PPNs were identified up to genus level and counted as promorphs; the forms easily recognizable at low magnification (less than $\times 100$ ) under stereomicroscope. For Meloidogyne spp., only infective juveniles were enumerated. Females and males (when present) were only used in species identification. Detailed observation on morphology, including genomic and mitochondrial DNA studies to characterize the enumerated promorph forms to their respective species was performed. A specific number of promorph specimens (depending on available population) were killed, fixed, and processed to pure glycerin (Seinhorst, 1959). Vulval cones and perineal patterns (for cyst and root-knot nematode species, respectively) were excised from healthy cysts and females as described by Van Bezooijen (2006). Measurements and micrographs were taken using a Zeiss imager Z2 microscope (Carl Zeiss, Gottingen, Germany) fitted with Axio-vision software: Material Science Software for Research and Engineering software (Carl Zeiss). The various promorphs/genera were characterized to species level according to diagnostic criteria using morphological, morphometric and molecular tools as detailed in Mwamula et al. (2020a, 2020b, 2020c, 2020d, 2020e, 2020f). Promorphs were corresponded to the identified species as described by Vandenbossche et al. (2011). Additionally, after the identification process, when a promorph or a single nematode population from the same genus conformed to more than one species, proportions of the individual species within the examined specimens were presumed to also represent the proportion of species in the counted population.

Data analysis. Diversity and related indices: The diversity of PPNs was analyzed by calculating various indices including mean intensity, maximum density, and prevalence (Boag, 1993). Mean intensity was calculated as the number of individuals of a particular nematode species per $300 \mathrm{~g}$ soil in positive samples divided by the total number of positive samples; maximum density was defined as the maximum number of individuals of a specified nematode species per $300 \mathrm{~g}$ soil recovered from a sample; and prevalence was presented as the number of samples positive for a particular nematode species divided by the total number of samples examined, expressed as percentages. Additionally, the following diversity indices were calculated according to Yeates and Bird (1994):

Evenness $J^{\prime}=H^{\prime} / H^{\prime} \max$

Dominance Index (Simpson's dominance): $D=\Sigma(n / N)^{2}$

Diversity H (Shannon Index $)=-\sum_{i=1}^{s} p_{i} \ln p_{i}$

Where $\mathrm{n}=$ number of individuals of one particular species in a sample; $N=$ total number of nematodes identified in the sample; $\mathrm{s}=$ number of taxa (species) in the sample; $p i=$ proportion of individuals of taxa $i$ in the total population; $H^{\prime} \max =\ln s$. Statistical differences among diversity indices, considering management zones were analyzed using Duncan's multiple range test $(P<0.05)$ in SAS ver. 9.3 (SAS Institute, Cary, NC, USA).

\section{Results}

Twenty-eight species/taxa belonging to 16 genera and 12 families of PPNs were identified and described from the 781 sod cores collected from the 13 golf courses distributed across Korea. Comprehensive morphological and molecular characterization of various studied taxa, including new species description were presented in the earlier published articles (Mwamula et al., 2020a, 2020b, 2020c, 2020d, 2020e, 2020f). Among the 28 species/taxa identified, 12 species/taxa (Tylenchorhynchus thermophilus, Pratylenchus 
Table 2. Occurrence and diversity of plant-parasitic nematodes (Tylenchida) in 13 golf courses

\begin{tabular}{|c|c|c|c|c|c|c|}
\hline \multirow{2}{*}{ Species } & \multicolumn{4}{|c|}{ Prevalence (\%) } & \multirow{2}{*}{$\begin{array}{c}\text { Mean } \\
\text { intensity }\end{array}$} & \multirow{2}{*}{$\begin{array}{c}\text { Maximun } \\
\text { density }\end{array}$} \\
\hline & BG & KBG & ZG & Combined & & \\
\hline Helicotylenchus microlobus & 4.2 & 16.9 & 59.2 & 78.9 & 343.3 & 1,160 \\
\hline Helicotylenchus dihystera & 1.4 & - & 1.4 & 2.8 & 513.5 & 813 \\
\hline Helicotylenchus caudatus & - & 1.4 & - & 1.4 & 17.0 & 29 \\
\hline Helicotylenchus asiaticus & - & 1.4 & - & 1.4 & 27.0 & 41 \\
\hline Tylenchorhynchus claytoni & 8.4 & 14.1 & 28.2 & 50.7 & 890.3 & 8,785 \\
\hline Tylenchorhynchus annulatus & - & 1.4 & 1.4 & 2.8 & 7.5 & 8 \\
\hline Tylenchorhynchus thermophilus & - & 1.4 & 1.4 & 2.8 & 101.8 & 183 \\
\hline Paralongidorus koreanensis & 2.8 & 4.2 & 12.6 & 19.7 & 71.5 & 164 \\
\hline Xiphinema diffusum & 1.4 & - & 5.6 & 7.0 & 53.2 & 73 \\
\hline Xiphinema insigne & - & - & 1.4 & 1.4 & 16.0 & 28 \\
\hline Paratrichodorus minor & - & 12.7 & 4.2 & 16.9 & 29.7 & 265 \\
\hline Mesocriconema sp. & 2.8 & 31 & 8.5 & 42.3 & 132.4 & 749 \\
\hline Mesocriconema curvatum & - & 1.4 & - & 1.4 & 30.5 & 38 \\
\hline Mesocriconema nebraskense & 4.2 & 42.3 & 15.5 & 62.0 & 238.3 & 1,392 \\
\hline Hemicriconemoides brachyurus & - & 12.7 & 1.4 & 14.1 & 40.5 & 46 \\
\hline Hemicycliophora labiata & - & 1.4 & - & 1.4 & 12.4 & 33 \\
\hline Paratylenchus nanus & - & 4.2 & - & 4.2 & $1,049.5$ & 2,094 \\
\hline Heterodera avenae & - & 1.4 & 1.4 & 2.8 & 21.5 & 33 \\
\hline Heterodera pratensis & - & 4.2 & - & 4.2 & 13.8 & 28 \\
\hline Pratylenchus penetrans & 2.8 & 4.2 & 5.6 & 12.7 & 22.4 & 119 \\
\hline Pratylenchus zeae & 1.4 & - & 4.2 & 7.0 & 33.5 & 21 \\
\hline Pratylenchus scribneri & 1.4 & - & 1.4 & 2.8 & 5.5 & 8 \\
\hline Ditylenchus sp. & - & - & 1.4 & 1.4 & 2.0 & 2 \\
\hline Neopsilenchus sp. & - & 1.4 & - & 1.4 & 2.0 & 3 \\
\hline Psilenchus hilarulus & - & 1.4 & - & 1.4 & 188.0 & 322 \\
\hline Filenchus sp. & - & 1.4 & - & 1.4 & 452.0 & 604 \\
\hline Meloidogyne graminicola & 4.2 & 15.5 & 7 & 26.8 & 76.7 & 1,185 \\
\hline Meloidogyne marylandi & - & 1.4 & 1.4 & 2.8 & 7.0 & 92 \\
\hline
\end{tabular}

BG, creeping bentgrass; KBG, Kentucky bluegrass; ZG, zoysiagrass.

zeae, Mesocriconema nebraskense, Mesocriconema sp., Neopsilenchus sp., Hemicycliophora labiata, Helicotylenchus caudatus, Helicotylenchus microlobus, Helicotylenchus asiaticus, Filenchus sp., Meloidogyne graminicola, and Paralongidorus koreanensis) are reported as new records in Korea. Details regarding the prevalence of each species in general, and with respect to grass species; including their mean intensities and maximum densities are shown in Table 2. H. microlobus (79\%), M. nebraskense (62\%), T. claytoni (50.7\%), Mesocriconema sp. (42.3\%), and M. graminicola $(26.8 \%)$ in their respective order, were generally the most prevalent species in all management zones. With respect to grass types (species) H. microlobus (59.2\%), T. claytoni (28.2\%), M. nebraskense (15.5\%), and P. koreanensis (12.6\%) were the most prevalent species on zoysiagrass (Zoysia japonica); M. nebraskense (42.3\%), H. microlobus (16.9\%), T. claytoni (14.1\%), M. graminicola
(15.5\%), and Paratrichodorus minor (12.7\%) dominated Kentucky bluegrass ( $P$. pratensis), while $T$. claytoni (8.4\%) represented the most prevalent species on bentgrass (Agrostis spp.).

The mean intensities of the different species ranged from two individuals (Neopsilenchus sp. and Ditylenchus sp.) to 1050 (Paratylenchus nanus). Other species with high mean intensities included; T. claytoni (890), Helicotylenchus dihystera (516), H. microlobus (343), Filenchus sp. (452), and $M$. nebraskense (238). Highest maximum densities per $300 \mathrm{~g}$ soil were displayed by T. claytoni $(8785$ individuals on $P$. pratensis); $P$. nanus (2,094 individuals on $P$. pratensis); $M$. nebraskense (1,392 individuals on P. pratensis); M. graminicola (1,185 infective juveniles on $P$. pratensis); and H. microlobus (1,160 individuals on $Z$. japonica). The influence of turfgrass management zone (fairways, tees and greens) on nematode population 
Table 3. Effect of management zones on nematode diversity on Korean golf courses

\begin{tabular}{lccc}
\hline Management zone & Diversity $H^{\prime}$ & Evenness $J^{\prime}$ & Dominance $D$ \\
\hline Putting greens & $1.32 \pm 0.03 \mathrm{~b}$ & $0.46 \pm 0.04 \mathrm{a}$ & $0.55 \pm 0.02 \mathrm{a}$ \\
Fairways & $1.61 \pm 0.03 \mathrm{a}$ & $0.67 \pm 0.05 \mathrm{a}$ & $0.79 \pm 0.02 \mathrm{a}$ \\
Tees & $1.31 \pm 0.04 \mathrm{~b}$ & $0.51 \pm 0.09 \mathrm{a}$ & $0.66 \pm 0.04 \mathrm{a}$ \\
Combination of all management zones & $1.94 \pm 0.02 \mathrm{a}$ & $0.63 \pm 0.04 \mathrm{a}$ & $0.78 \pm 0.02 \mathrm{a}$ \\
\hline
\end{tabular}

Means fallowed by the same letters denote no significant differences at $P \leq 0.05$ by the Duncan's multiple range test.

diversity indices are presented in Table 3. Species evenness $\left(J^{\prime}\right)$ and dominance $(D)$ showed no statistically significant differences between the management zones. However, Diversity $\left(H^{\prime}\right)$, was significantly higher in fairways compared to tees and greens.

\section{Discussion}

Our study represents one of few major detailed species characterizations done on turfgrass worldwide. Twentyfour species of PPNs were isolated from golf courses in North and South Carolina in USA by Zeng et al. (2012); while 52 different species/taxa were identified morphologically from both golf courses and football pitches in Belgium (Vandenbossche et al., 2011). In Korea, there has been limited information on incidence and damage potential of PPNs on turf; with only four species: M. incognita, T. claytoni, M. marylandi, and T. dubius, recorded (Choo et al., 2000; Kang et al., 2002; Khan et al., 2008); two of which ( $M$. incognita and $T$. claytoni) have been implicated in turfgrass damage. Other records have been identified to genus level (Kang et al., 2002). Thus, the current study provides information for nematode species diagnosis on turf in Korea and a basis for developing proper control techniques for sustainable turfgrass management system. Investigations carried out in the past have showed that nematodes belonging to genera Mesocriconema, Belonolaimus, Helicotylenchus, Hoplolaimus, Hemicycliophora, Pratylenchus, Meloidogyne, Tylenchorhynchus, Paratrichodorus, and Trichodorus, constitute the most turfgrass associated nematode problems on both cool and warm season grasses (Sikora et al., 2001; Vandenbossche et al., 2011; Walker et al., 2002; Zeng et al., 2012). Similar findings were evident in the current study. H. microlobus, M. nebraskense, $T$. claytoni, Mesocriconema sp., and M. graminicola were recorded herein as the most prevalent species in all management zones. H. microlobus, T. claytoni, M. nebraskense, and $P$. koreanensis were more prevalent on zoysiagrass and Kentucky bluegrass. M. graminicola and $P$. minor were more prevalent on Kentucky bluegrass. Commensurate to studies of Zeng et al. (2012), this study highlights the limited influence of grass type on the most common PPN species, though species like $M$. graminicola and $P$. minor were mainly isolated from Kentucky bluegrass compared to zoysia and bentgrass samples. Therefore, species specificity is only restricted to few uncommon nematode pathogens of turfgrass. Generally, nematode prevalence in creeping bentgrass was low, with only $T$. claytoni recording a relatively higher prevalence. However, it should also be noted that creeping bentgrass constitute the minority of the golf course surface area covered by turf. In Korea, preference is mainly given to Kentucky bluegrass and zoysia and therefore, this explains the high prevalence of PPNs on the two grass types since a limited number of samples were collected from creeping bentgrass covered surfaces.

Zeng et al. (2012) isolated higher number of PPN species in bermudagrass than in creeping bentgrass and zoysiagrass. However, their results also highlighted that the prevalence of PPNs may not necessarily be influenced by turfgrass type, as soil types are equally known to play a vital role in determining PPN prevalence. It is indeed known that most PPN damages on turfgrass occur in sandy soils (Crow, 2005). Our results are in agreement with this concept and damage of turfgrass on Korean golf courses might be more pronounced as most of the golf courses sampled are predominantly covered by sandy soils or loamy sand soils. Putting greens are normally constructed with more than $90 \%$ sand (Crow, 2005). This possibly explains why the highest maximum densities displayed by $T$. claytoni, $P$. nanus, $M$. nebraskense, and $M$. graminicola were recorded on $P$. pratensis, a common grass type cover used on putting greens in Korea. Some nematode species like $P$. nanus with low prevalence showed high mean intensity and maximum densities; a finding that represents and supports the notion of extreme host specificity in uncommon PPNs on turfgrass.

Species diversity indices; evenness $\left(J^{\prime}\right)$ and dominance $(D)$ showed no significant differences among the management zones. However, diversity $\left(H^{\prime}\right)$, was relatively higher in fairways compared to tees and putting greens. These results agree with the findings of Zeng et al. (2012) except for the differences in $H^{\prime}$. However, their results 
also showed a significant difference between zoysiagrass and other turfgrass species; with zoysiagrass showing a higher $H^{\prime}$ value compared to other grass types. In the current study, fairways are largely covered by zoysiagrass and therefore, this explains the differences in index $H^{\prime}$. It is evident that there appears to be higher diversity of PPN species on zoysiagrass than in other grass types. It should be noted however that the distribution and fluctuation differences among nematode populations are a common phenomenon in turfgrass ecosystem studies, and different PPN populations have been showed to fluctuate depending on factors like season and root establishments (Jordan and Mitkowski, 2006; McGroary et al., 2009; Settle et al., 2006). More studies are thus justifiable to better understand factors influencing the dynamics of various important nematodes. Additionally, quantification or estimates of turfgrass damage and revenue losses caused by PPNs still remains a challenge due to the atypical symptoms and disease complexes the nematodes cause in association with other pathogens. At high population infestations, total turfgrass death becomes imminent especially involving specific nematode-turfgrass combinations (Hunt and Handoo, 2009; McClure et al., 2012; Vandenbossche et al., 2011). In our study, high nematode populations were associated with stunted growth, lowered turf stands, shoot chlorosis/ yellowing of leaves, and generally a low sod vigor in the sites selected during sampling. Such sites often translated into high maximum densities of the various species deemed to be serious pathogens on turf like Mesocriconema spp., Helicotylenchus spp., Paratrichodorus minor and Meloidogyne spp. Root-knot nematodes like Meloidogyne minor and other key species like $H$. microlobus have been shown to cause yellow patch disease on turf in Europe and USA, respectively (Karssen et al., 2004; Subbotin et al., 2011, 2015).

In conclusion, this study provides a baseline of information on occurrence, and diversity of various species of PPNs on turfgrass in Korea and highlights the key prevalent species associated with turf damage on Korean golf courses. It is evident that damage of turfgrass by nematodes on golf courses has been a hidden mystery and the current findings calls for devising and dispensation of proper appropriate PPN management techniques to enable proper management of turf and thus keep nematode damages below economic threshold levels.

\section{Conflicts of Interest}

No potential conflict of interest relevant to this article was reported.

\section{Acknowledgments}

The authors thank Dr. Sergei A. Subbotin (California Department of Food and Agriculture Plant Pest Diagnostic Center, CA, USA) for the technical advices during the species identifications. The authors also acknowledge the respective golf course superintendents and students in turfgrass pests and nematology laboratory for their cooperation during the survey.

\section{References}

Barker, K. R., Nusbaum, C. J. and Nelson, L. A. 1969. Effects of storage temperature and extraction procedure on recovery of plant-parasitic nematodes from field soils. J. Nematol. 1:240247.

Boag, B. 1993. Standardization of ecological terms in nematology. Fundam. Appl. Nematol. 16:190-191.

Choo, H. Y., Lee, D. W., Kim, H. H., Park, J. W., Sung, Y. T. and Chung, Y. K. 1998. A newly recorded turfgrass pest, root-knot nematode, Meloidogyne incognita in Korean golf courses. Korean Turfgrass Sci. 12:107-112.

Choo, H. Y., Lee, D. W., Lee, S. M., Lee, T. W., Choi, W. G., Chung, Y. K. and Sung, Y. T. 2000. Turfgrass insect pests and natural enemies in golf courses. Korean J. Appl. Entomol. 39:171-179 (in Korean).

Crow, W. T. 2005. Plant-parasitic nematodes on golf course turf. Outlooks Pest Manag. 16:10-15.

Crow, W. T., Giblin-Davis, R. M. and Lickfeldt, D. W. 2003. Slit injection of 1,3-dichloropropene for management of Belonolaimus longicaudatus on established bermudagrass. $J$. Nematol. 35:302-305.

Fleming, C. C., Craig, D., Hainon-McDowell, M. and Entwistle, K. 2008. Plant parasitic nematodes: a new turf war? Biologist 55:76-82.

Gramckow, J. 1968. Athletic field quality studies. Cal-Turf Inc., Camarillo, CA, USA. 49 pp.

Hunt, D. J. and Handoo, Z. A. 2009. Taxonomy, identification and principal species. In: Root-knot nematodes, eds. by R. N. Perry, M. Moens and J. L. Starr, pp. 55-97. CABI, Wallingford, UK.

Jenkins, W. R. 1964. A rapid centrifugal-floatation technique for separating nematodes from soil. Plant Dis. Rep. 48:692.

Jordan, K. S. and Mitkowski, N. A. 2006. Population dynamics of plant-parasitic nematodes in golf course greens turf in Southern New England. Plant Dis. 90:501-505.

Kang, B., Kabir, F. M., Bae, E.-J., Lee, G. S., Jeon, B. and Lee, D. W. 2016. Damage report on a newly recorded coleopteran pest, Aphanisticus congener (Coleoptera: Buprestidae) from turfgrass in Korea. Weed Turf. Sci. 5:274-279.

Kang, S. J., Park, B. Y., Choi, D. R. and Han, S. C. 2002. First report of Meloidogyne marylandi (Tylenchida : Heteroderidae) in Korea. Korean J. Soil Zool. 7:45-49 (in Korean).

Kang, Y. J., Lee, D. W., Choo, H. Y., Kweon, T. W., Shin, C. J., 
Shin, H. K., Choi, I. G. and Choi, Y. E. 2003. Turfgrass nematodes isolated from some golf courses. Korean Turfgrass Sci. 17:81-85 (in Korean).

Karssen, G., Bolk, R. J., Van Aelst, A., van den Beld, I., Kox, L., Korthals, G., Molendijk, L., Zijlstra, C., Van Hoof, R. and Cook, R. 2004. Description of Meloidogyne minor n. sp. (Nematoda: Meloidogynidae), a root-knot nematode associated with yellow patch disease in golf courses. Nematology 6:59-72.

Khan, Z., Kim, J.-H., Son, S.-H., Kim, S.-G. and Kim, Y.-H. 2008. Occurrence of stunt nematode, Tylenchorhynchus claytoni, on turfgrass in Korea. Plant Pathol. J. 24:474-477.

Kim, H. K. 1991. Turfgrass science. Sunjinmunhwasa, Seoul, Korea. 545 pp.

Kim, J., Mwamula, A. O., Kabir, F., Shin, J. H., Choi, Y. H., Lee, J.-K. and Lee, D. 2016. Efficacy of different nematicidal compounds on hatching and mortality of Heterodera schachtii infective juveniles. Korean J. Pestic. Sci. 20:293299.

Lee, C. M., Kweon, O.-G., Lee, K.-S., Lee, S.-M., Choi, S. and Lee, D. W. 2014. Insect pests in turf sod production areas in Korea. Weed Turf. Sci. 3:114-120.

McClure, M. A., Nischwitz, C., Skantar, A. M., Schmitt, M. E. and Subbotin, S. A. 2012. Root-knot nematodes in golf course greens of the western United States. Plant Dis. 96:635-647.

McGroary, P., Crow, W. T., McSorley, R., Giblin-Davis, R. M. and Cisar, J. L. 2009. Seasonal fluctuations of Belonoiaimus longicadatus in bermudagrass. Nematropica 39:99-110.

Mwamula, A. O., Decraemer, W., Kim, Y. H., Ko, H.-R., Na, H., Kim, Y. H. and Lee, D. W. 2020a. Description of a new needle nematode, Paralongidorus koreanensis n. sp., and two known Xiphinema spp. cobb, 1913, from turfgrass in Korea. Eur. J. Plant Pathol. 156:1-20.

Mwamula, A. O., Kabir, M. F., Lee, G., Choi, I. H., Kim, Y. H., Bae, E.-J. and Lee, D. W. 2020b. Morphological characterisation and molecular phylogeny of several species of Criconematina (Nematoda: Tylenchida) associated with turfgrass in Korea, as inferred from ribosomal and mitochondrial DNA. Nematology 22:939-956.

Mwamula, A. O., Kim, Y. H., Lee, H. W., Bae, E.-J., Kim, Y. H. and Lee, D. W. 2020c. Taxonomic notes on three Tylenchorhynchus spp. (Nematoda, Telotylenchidae) associated with turfgrass in Korea. Eur. J. Plant Pathol. 156:1101-1117.

Mwamula, A. O., Kim, Y. H., Na, H., An, H. J., Kim, Y. H. and Lee, D. W. 2020d. Molecular characterisation and phylogenetic position of Hemicycliophora labiata Colbran, 1960, from turfgrass in Korea, with comments on its morphology. Nematology 22:927-938.

Mwamula, A. O., Lee, G., Kim, Y. H., Kim, Y. H., Lee, K. and Lee, D. W. 2020e. Molecular phylogeny of several species of Hoplolaimina (Nematoda: Tylenchida) associated with turfgrass in Korea, with comments on their morphology. Nematology 23:559-576.

Mwamula, A. O., Na, H., Kim, Y. H., Kim, Y. H., Han, G. and Lee, D. W. 2020f. Characterization of a new spiral nematode,
Helicotylenchus asiaticus n. sp., and three known species from Korea; with comments on the validity of Helicotylenchus microlobus Perry in Perry, Darling \& Thorne, 1959. Eur. J. Plant Pathol. 157:565-581.

Perry, V. G. and Smart, G. C. Jr. 1970. Nematode problems of turfgrasses in Florida and their control. Proc. Fla. State Hortic. Soc. 83:489-492.

Seinhorst, J. W. 1959. A rapid method for the transfer of nematodes from fixative to anhydrous glycerin. Nematologica 4:67-69.

Settle, D. M., Fry, J. D., Todd, T. C. and Tisserat, N. A. 2006. Population dynamics of the lance nematode (Hoplolaimus galeatus) in creeping bentgrass. Plant Dis. 90:44-50.

Sikora, E. J., Guertal, E. A. and Bowen, K. L. 2001. Plantparasitic nematodes associated with hybrid bermudagrass and creeping bentgrass putting greens in Alabama. Nematropica 31:301-305.

Subbotin, S. A., Inserra, R. N., Marais, M., Mullin, P., Powers, T. O., Roberts, P. A., van den Berg, E., Yeates, G. W. and Baldwin, J. G. 2011. Diversity and phylogenetic relationships within the spiral nematodes of Helicotylenchus Steiner, 1945 (Tylenchida: Hoplolaimidae) as inferred from analysis of the D2-D3 expansion segments of 28S rRNA gene sequences. Nematology 13:333-345.

Subbotin, S. A., Vovlas, N., Yeates, G. W., Hallmann, J., Kiewnick, S., Chizhov, V. N., Manzanilla-López, R. H., Inserra, R. N. and Castillo, P. 2015. Morphological and molecular characterisation of Helicotylenchus pseudorobustus (Steiner, 1914) Golden, 1956 and related species (Tylenchida: Hoplolaimidae) with a phylogeny of the genus. Nematology 17:27-52.

Van Bezooijen, J. 2006. Methods and techniques for nematology. Wageningen University, Wageningen, Netherlands. 112 pp.

Vandenbossche, B., Viaene, N., Sutter, N., Maes, M., Karssen, G. and Bert, W. 2011. Diversity and incidence of plant-parasitic nematodes in Belgian turf grass. Nematology 13:245-256.

Wada, S. and Toyota, K. 2008. Effect of three organophosphorous nematicides on non-target nematodes and soil microbial community. Microbes Environ. 23:331-336.

Wada, S., Toyota, K. and Takada, A. 2011. Effects of the nematicide imicyafos on soil nematode community structure and damage to radish caused by Pratylenchus penetrans. J. Nematol. 43:1-6.

Walker, N. R., Goad, C. L., Zhang, H. and Martin, D. L. 2002. Factors associated with populations of plant-parasitic nematodes in bentgrass putting greens in Oklahoma. Plant Dis. 86:764-768.

Yeates, G. W. and Bird, A. F. 1994. Some observations on the influence of agricultural practices on the nematode faunae of some South Australian soils. Fundam. Appl. Nematol. 17:133145.

Zeng, Y., Ye, W., Bruce Martin, S., Martin, M. and Tredway, L. 2012. Diversity and occurrence of plant-parasitic nematodes associated with golf course turfgrasses in North and South Carolina, USA. J. Nematol. 44:337-347. 